Gazi University
Journal of Science
$\mathrm{http} / /$ dergipark.gov.tr/gujs

\title{
Energy Consumption Analysis of Education Buildings: The Case Study of Balikesir University
}

\author{
Yusuf YILDIZ* (iD), Merve KOCYIGIT \\ Department of Architecture, Balikesir University, 10145, Ballkesir, Turkey
}

\author{
Highlights \\ - This paper focuses on energy consumption per unit area of the surveyed buildings. \\ - There is significant difference in energy consumption of buildings. \\ - Five buildings are responsible from $70 \%$ of total energy consumption of university campus
}

\begin{tabular}{l} 
Article Info \\
\hline Received:18 Apr 2020 \\
Accepted:01 Jan 2021 \\
Keywords \\
\hline University buildings \\
Energy use \\
Energy plan \\
Case study
\end{tabular}

\section{INTRODUCTION}

The building industry is responsible from $20-40 \%$ of worldwide energy use [1] and, in addition to the industry and transportation sectors, it has become one of the three main energy exhausting sectors. This increases the necessity for energy use efficiently in buildings and associated greenhouse gas emissions reduction. It also provides an important opportunity to save large-scale energy [2]. After the publication of the Energy Performance of Buildings directive, interest in energy efficiency has increased [3]. Environmental problems due to increasing carbon emissions from usage of conventional fuels [4] causes the development of new solutions and approaches to the questioning of the energy saving in the buildings.

For most of the countries, education buildings and businesses are the center of issues about energy consumption, and education buildings led to important energy use and carbon dioxide emissions compared to other buildings [5]. Within the educational buildings, university campuses have complex functions by providing space for various activities and disciplines. University campuses with office buildings, libraries, hotels, student dormitories, restaurants, shops, sports facilities, entertainment complexes, health centers, laboratories and educational buildings, having different features and changing energy needs behaves like small cities [6]. It has an important local socioeconomic effect in cities due to its scales and development potential. Therefore, analyzing energy consumption for different buildings on university campuses can help to understand their energy use characteristics and provide opportunities to decrease usage energy in campuses on a large scale [7]. Understanding energy use of campus buildings can also guide how to improve energy efficiency in buildings and cities. 
In Turkey, there are lots of universities. Considering the change of the number of universities by years, a significant increase is observed. While the number of universities was 27 in 1982, with the establishment of 24 new universities in 1992, the total number of universities reached 51. In addition, in 1992, foundations were allowed to open higher education institutions, after which 22 foundations and 2 state universities were established. Thus, after 2005, the total number of universities became 77 [8]. In the face of the increase in the demand for higher education, the biggest increase in the number of universities has occurred since 2006, especially between 2006-2008 [9]. With the establishment of 16 universities in 2006 and 23 new universities in 2007, the total number of universities became 115 [8]. As of the end of October 2015, there were 185 universities (109 states and 76 foundations) in Turkey. In 2020, the total number of universities is 207 (129 states, 73 foundations and 5 foundation vocational schools) [10]. Increasing the number of universities will increase the need for buildings. It is clear that analyzing the energy consumption of settlements including large numbers of buildings, such as university campuses, can provide ideas to build energy consumption models and can uncover the energy savings potential for individual buildings on a large scale $[7,11]$.

In the literature, there are various studies focusing on the analysis of energy consumption, especially for educational buildings: Hong et al. [12] chose the sixth university consuming high energy in Korea and examined its energy use model. After analyzing the types and quantities of energy consumed in campus buildings, an increasing tendency was estimated, and an optimized and limited version of future energy need was calculated. Hawkins et al. [13] used the artificial neural networks method to analyze wider energy use determinants in London university buildings. It was realized that the use of electricity was generally high and the use of fuel for heating was low compared to the CIBSE TM46 criteria. Deshko et al. [14] revealed the possibilities and problems of using the certification to specify the energy efficient precautions for university campuses. Zhou et al. [15] conducted a detailed survey for six years for the energy consumption of colleges and universities, containing the use of electricity, water, gas and cooling energy in Guangdong Province, China. The survey showed that there is a big difference in unit energy use among different university types classified by school discipline, nature and level. Escobedo et al. [16] predicted energy consumption and related greenhouse gas emissions for the buildings and facilities in the main campus of the National Autonomous University of Mexico. It has also developed an analysis that predicts consumption reduction scenarios involving energy efficient technologies and solar water heating. Chung et al. [17] performed an on-site field study in current university buildings to identify existing energy use models and energy saving strategies to increase energy efficiency. Guan et al. [18] developed a methodology to determine the energy use features of university building stocks in terms of energy planning. The results of this study can be helpful for energy planning of cities and other urban energy systems. Sait [19] studied the electrical energy usage of an educational building located in Rabigh, $150 \mathrm{~km}$ north of Jeddah, Saudi Arabia. Detailed auditing was made in the building about materials, energy consumption for cooling load and lighting. As a result of the audit, some suggestions were presented to decrease the electrical energy consumption, which can reach up to $35.3 \%$. It had been observed that the efficiency of A/C units could be increased up to $31 \%$. Sekki et al. [20] measured the energy consumption in current educational buildings. It shows a general picture of energy consumption and evaluates the factors used to understand the consumed energy. The buildings measured energy were daycare centers, schools and university buildings in Southern Finland. This study showed that, although the Finnish climate was cold, primary electricity consumption was higher than heating energy usage in education buildings built in the 2000s. Khoshbakth et al. [21] aimed to understand the energy consumption features of different types of buildings on higher education campuses and to conduct an energy comparison system. The data were taken from 80 university buildings in Australia. Regarding the activities, the buildings used for research have the highest value with $216 \mathrm{kWh} / \mathrm{m} 2 /$ year and academic office buildings have the lowest value with $137 \mathrm{kWh} / \mathrm{m} 2 /$ year. Wang [5] investigated the final energy consumption in 67 high schools, 62 secondary schools and 102 primary schools in Taiwan. In this study, it was observed that air conditioning and lighting greatly affected the electricity consumption of school buildings.

Although the energy efficiency in university campuses has attracted the attention of university administrators and professionals in recent years, this issue has not become widespread enough [21, 22]. Data on the contribution of educational buildings to total energy consumption could not be obtained for Turkey. However, understanding the energy consumption in university campuses other than individual 
buildings is a significant prerequisite for understanding how to increase energy efficiency and how to plan energy usage of campuses [23,24]. Comparing energy use in buildings can show empirical evidence on the performance of sustainable buildings according to current building stock [2]. University campuses consist of different building groups with significant energy consumption. Thus, they ensure a helpful test facility to describe the energy consumption of a group of mixed-use buildings. Another benefit of study university campus is the dissemination of results. One of the important issues is that despite the increased energy need in university campuses, it is difficult to find enough data on the energy usage of university buildings in Turkey. For this reason, main objective of this study is to analyze the annual energy consumption of the buildings in Balıkesir University Çağış Campus and compare them in various ways. The results will be beneficial for designers, engineers and related specialists who want to examine the energy performance of buildings over the existing building stock. The results can also contribute to identifying buildings consuming high energy consumption and buildings where need the energy efficient improvement firstly. Monitoring and comparing the energy performance of current buildings is crucial for ensuring energy efficiency when used as design goals for new buildings or energy efficient improvement projects [25]. It should be noted that the scope of this study is limited to the buildings located in Balıkesir University Çağış Campus.

\section{MATERIAL METHOD}

The comparison of energy consumptions can be made by using basic or more advanced statistical methods [2]. The most commonly used method in the literature are simple descriptive statistics and are based on relative performance indicators by normalizing energy consumption per floor area and adjusting to climate data [26]. For example, energy use intensity indicator $\left(\mathrm{kWh} / \mathrm{m}^{2} /\right.$ year), which is used as an assessment tool in most countries, refers to the total amount of all forms of energy consumed in a year (fuel oil, natural gas and electricity). To calculate the energy use intensity indicator, the amount of energy consumed is first converted to $\mathrm{kWh}$, and then this number is divided into the total floor area of the building to obtain the energy consumption value for per unit of base area [5]. The approach used to carry out this study includes the following steps: choosing the university, compiling building and energy consumption data, making detailed analysis. In other words, firstly, general comparisons were made according to energy consumption per $\mathrm{m}^{2}$ and per person. Then it was compared based on energy use intensity indicator for each building. Moreover, contribution of individual buildings to total energy consumption in campus were calculated and discussed. Lastly, energy consumption of buildings from Balikesir University Çağış Campus were compared buildings from other countries. The information used in this research consists of architectural and mechanical project drawings, on-site inspections and the actual monthly energy consumption data. Heating consumption includes space heating and ventilation air heating. Electricity consumption covers cooling, all kinds of electrical equipment and lighting.

\subsection{University and General Features of Buildings}

Balıkesir University Çağış Campus, which is the study area, was built on the land of 5.000 decares. The campus is at the 17th km of Balıkesir-Bigadiç road (Figure 1).

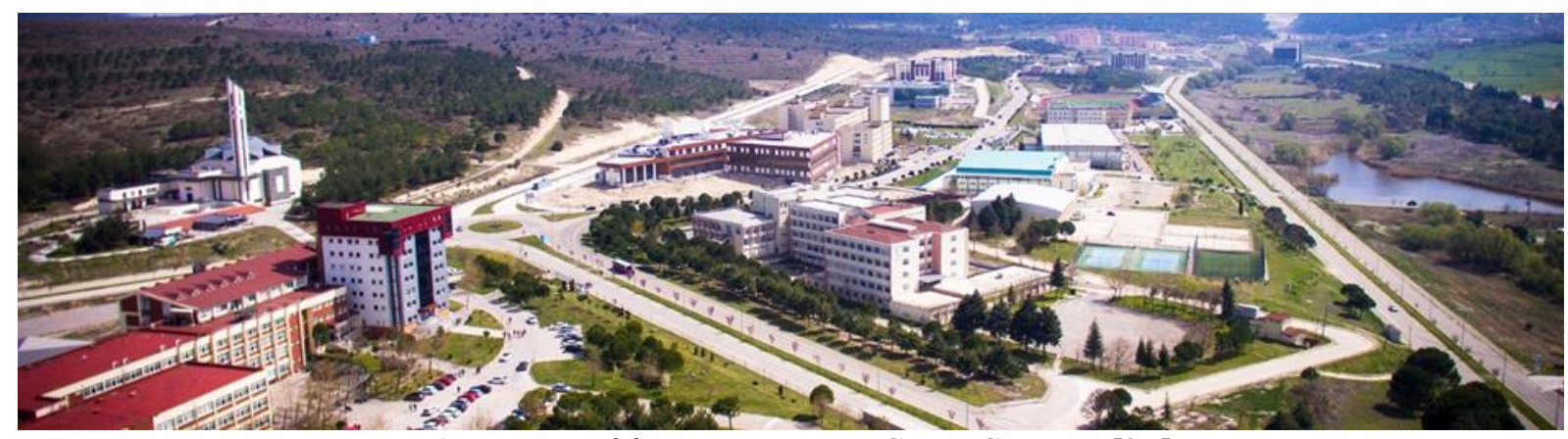

Figure 1. Balıkesir University Çağış Campus [27]

The area, functions, and construction year of the buildings on the Çağış campus are given in Table 1 . 
Table 1. Basic information of Çă̆ış Campus buildings

\begin{tabular}{|c|c|c|c|c|c|c|}
\hline Building name & Intended use & $\begin{array}{c}\text { Construction } \\
\text { year }\end{array}$ & $\begin{array}{l}\text { Building } \\
\text { floor area } \\
\left(\mathrm{m}^{2}\right)\end{array}$ & $\begin{array}{l}\text { Building } \\
\text { total area } \\
\left(\mathrm{m}^{2}\right)\end{array}$ & $\begin{array}{c}\text { Total } \\
\text { heated } \\
\text { area }\left(\mathrm{m}^{2}\right)\end{array}$ & $\begin{array}{c}\text { Total } \\
\text { cooled } \\
\text { area }\left(\mathrm{m}^{2}\right)\end{array}$ \\
\hline 01-Balikesir Vocational School & Education & 1992 & 4074 & 14993 & 12155 & 2000 \\
\hline 02- Faculty of Engineering and Architecture & Education & 1993 & 5417 & 20001 & 18000 & 3600 \\
\hline 03- Faculty of Tourism & Education & 1993 & 4134 & 12404 & 10000 & 1600 \\
\hline 04- Faculty of Science and Letters & Education & 1994 & 6201 & 28021 & 25500 & 3500 \\
\hline 05 - Building of rectorate & Office + library & 1996 & 1770 & 15202 & 13000 & 13000 \\
\hline 06-Hotel & $\begin{array}{l}\text { Education }+ \\
\text { accommodation }\end{array}$ & 1997 & 5234 & 14316 & 10000 & 0 \\
\hline 07- Gymnasium & Sport & 2000 & 3464 & 10394 & 5000 & 1000 \\
\hline 08- Medico Social Building & $\begin{array}{l}\text { Health + } \\
\text { Education }\end{array}$ & 2001 & 2623 & 10492 & 7000 & 4000 \\
\hline 09-Dining Hall & Social & 2007 & 5613 & 11226 & 9000 & 8000 \\
\hline 10-Engineering Workplace & Laboratory & 2008 & 564 & 1694 & 700 & 0 \\
\hline 11- Faculty of Medicine Hospital & Education & 2010 & 2670 & 29603 & 20000 & 18000 \\
\hline 12- School of Physical Education and Sports & Education & 2010 & 5414 & 9020 & 7938 & 1533 \\
\hline $\begin{array}{l}\text { 13- Faculty of Economics and Administratives } \\
\text { Sciences }\end{array}$ & Education & 2010 & 2815 & 13132 & 11500 & 8000 \\
\hline 14- Indoor Swimming Pool & Sport & 2010 & 1651 & 4953 & 2000 & 1000 \\
\hline 15- Main Laboratory & Laboratory & 2010 & 1279 & 3838 & 2200 & 1000 \\
\hline 16-Dormitory & Accommodation & 2011 & 3577 & 28623 & Unknown & Unknown \\
\hline 17- Faculty of Veterinary & Education & 2011 & 2815 & 13132 & 10000 & 5000 \\
\hline 18- Faculty of Engineering & Education & 2014 & 4200 & 17860 & 13000 & 10000 \\
\hline 19- Laboratory Animals Center & Laboratory & 2014 & 468 & 812 & 600 & 600 \\
\hline 20- Faculty of Medicine & $\begin{array}{l}\text { Health }+ \\
\text { Education }\end{array}$ & 2014 & 4998 & 19328 & 14000 & 10000 \\
\hline
\end{tabular}

They are generally educational buildings, and as seen in Figure 2, most of them were built in 2010 and before.

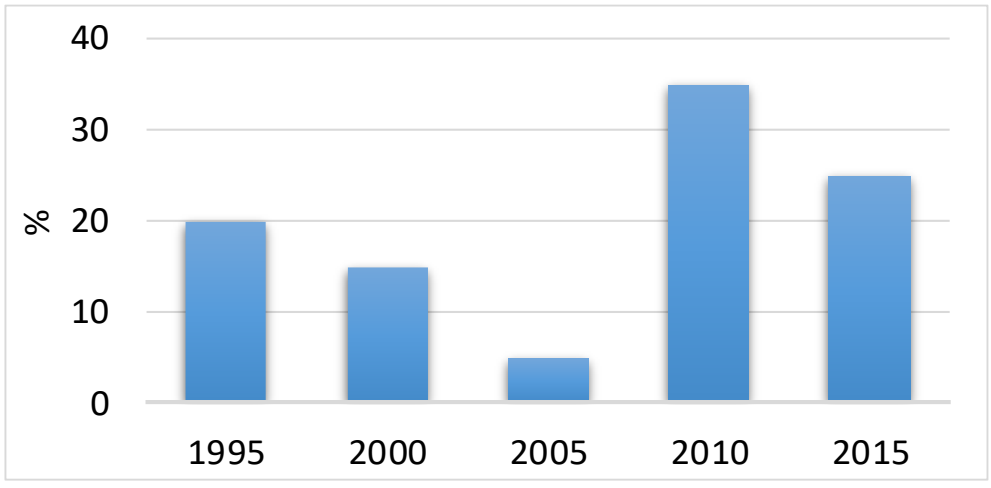

Figure 2. Annual building construction rate 
Bal1kesir Vocational School is the oldest building and it was constructed in 1992. The newest building is Faculty of Medicine, Laboratory Animals Center and Faculty of Engineering and it was built in 2014. The smallest building with $812 \mathrm{~m}^{2}$ is the Laboratory Animals Center, while the largest building is the Faculty of Arts and Sciences with $34190.95 \mathrm{~m}^{2}$. As of the end of 2019, the total closed area of 20 buildings is $65179,817 \mathrm{~m}^{2}$. Among the 20 buildings shown in Table 1, there are 7 faculties with a total of 115307 students and 2 vocational schools with 5538 students between 2008 and 2019. As seen in Figure 3, the number of all students continued to increase steadily every year until 2016. Between 2008 and 2016, the rate of increase every year is $8.20 \%$ on average. After 2016, there has been a reduction in the number of students due to the decline in the preference rates of some departments. Compared to 2008, the total number of students increased by $61.9 \%$ in 2019 .

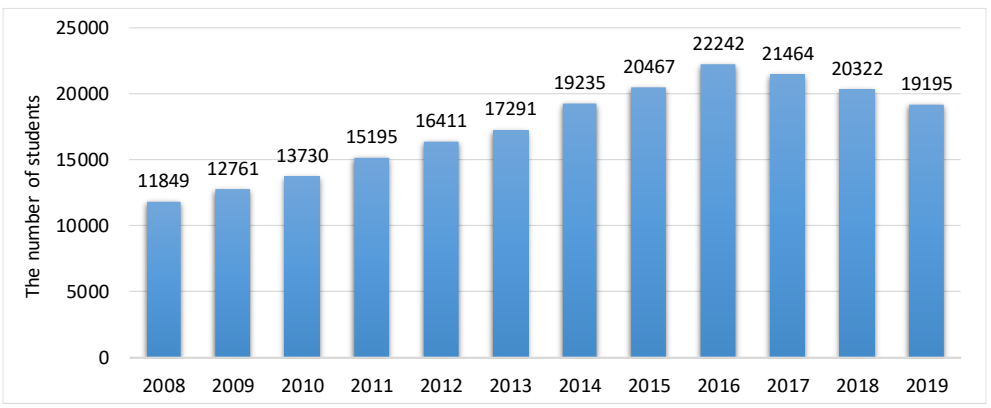

Figure 3. Total number of students per year

The number of students per building in 2019 is shown in Figure 4. While the building with the highest number of students is Balıkesir Vocational School, the building with the lowest number of students is the Faculty of Veterinary.

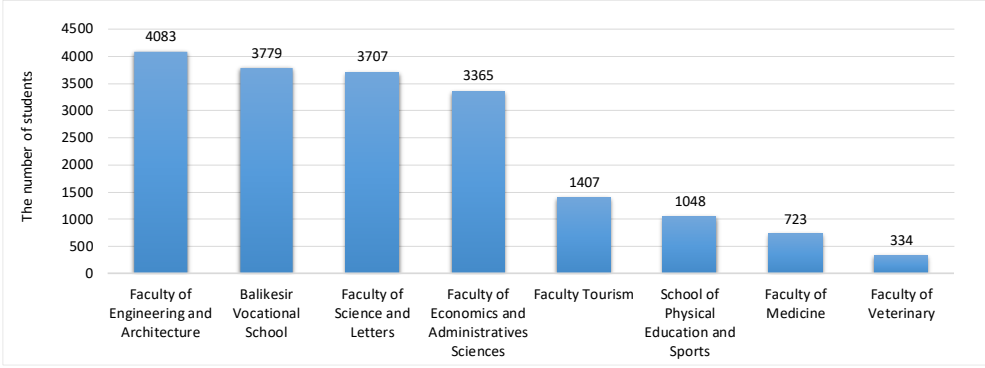

Figure 4. Number of students per building in 2019

The change in the number of staff by years increases almost every year (in Figure 5). Compared to 2008, the number of staff increased by $65 \%$ in 2019 .

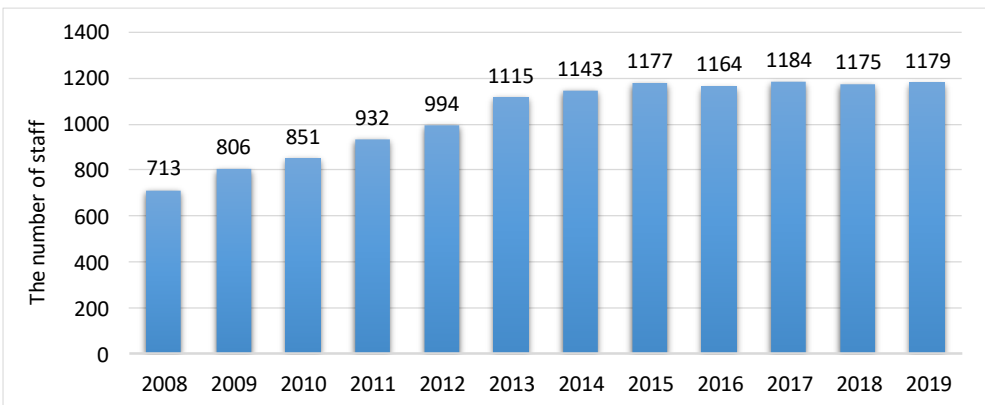

Figure 5. Total number of staff between 2008-2019 


\section{THE RESEARCH FINDINGS AND DISCUSSION}

In this study, natural gas and electricity were accepted as the main energy sources used on campus. The actual electricity and natural gas monthly consumption values for some of the buildings at Balıesir University Çağış Campus, which is reached between 2008-2019, were taken from the relevant institutions and the data of 10 years were evaluated. Natural gas consumption values of Laboratory Animals Center and Faculty of Tourism and electricity consumption values of Faculty of Engineering Building, Engineering Workplace and Indoor Swimming Pool have not been reached. In addition, the Faculty of Engineering and Architecture and the Building of rectorate were handled together as they were jointly billed in electricity consumption. As the Dormitory belongs to the private sector, its natural gas and electricity consumption values could not be obtained and evaluated. However, electricity and natural gas consumption data of other buildings on campus have been investigated in detail. In this section, firstly, energy use intensities for natural gas and electricity consumption were calculated and compared. Then, the contribution of campus buildings to total energy consumption was analyzed. Finally, according to the consumption values of 2019, the energy use intensities of the buildings were compared with the amount of energy consumed by educational buildings in different countries in the literature.

\subsection{Annual Total Natural Gas and Electricity Consumptions}

The total natural gas consumption of the buildings on campus by years was showed in Figure 6. It is observed that natural gas consumption has increased significantly until 2015.

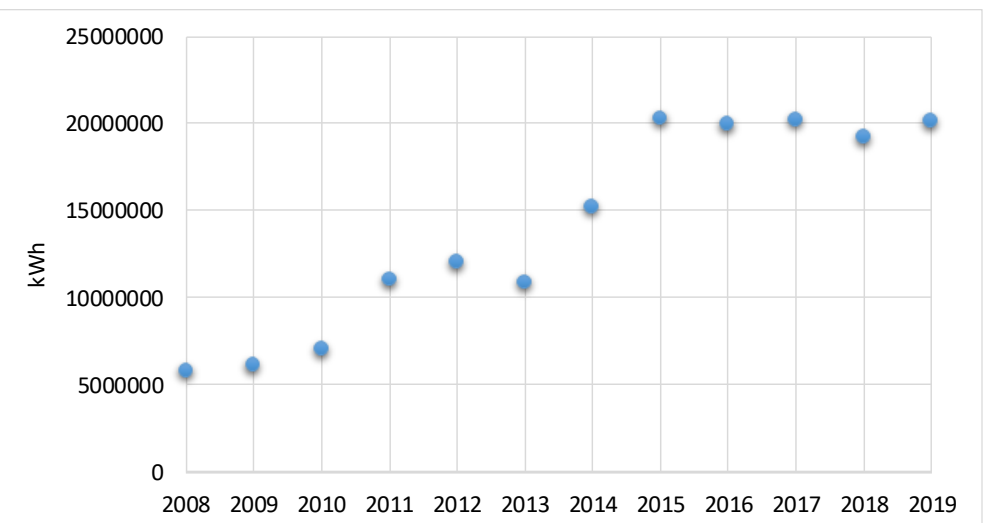

Figure 6. Annual total natural gas consumption $\left(1 \mathrm{~m}^{3}\right.$ natural gas $\left.=10.64 \mathrm{kWh}\right)$

In general, this increment may be due to the construction of new buildings and the increasing number of students each year. For example, natural gas consumption was started to consume in the Dining Hall and Gymnasium in 2011 and the Faculty of Medicine Hospital, Faculty of Economics and Administrative Sciences, Main Laboratory, Engineering Workplace and School of Physical Education and Sports in 2014. The number of students in these years increased by $10 \%$ compared to previous years. In 2011, the average annual outdoor temperature in most part of Turkey was around normal, whereas it was below their normal levels in Manisa, Balıkesir, Emirdağ, Çankırı, Batman and Bitlis [28]. This situation may lead to increase natural gas consumption in 2011. In 2013, natural gas consumption decreased by $9.43 \%$ compared to 2012 . The monthly average outdoor temperature in 2013 was above the norms based on 1981-2010 in January, February, March, April, May, June, August and November [29]. The probable reason for the decrease in consumption is high air temperatures in this year. this could affect the total consumption value. It is very clear that total natural gas consumption increased by $350 \%$ in 2019 compared to 2008.

Annual natural gas consumption per person (student + staff) is given in Figure 7. It is found that it varied greatly and reached its peak in 2015 with $993 \mathrm{kWh}$. The possible reason for this is the newly built buildings. Later, due to the change in the number of students, a spatial consumption occurred. 


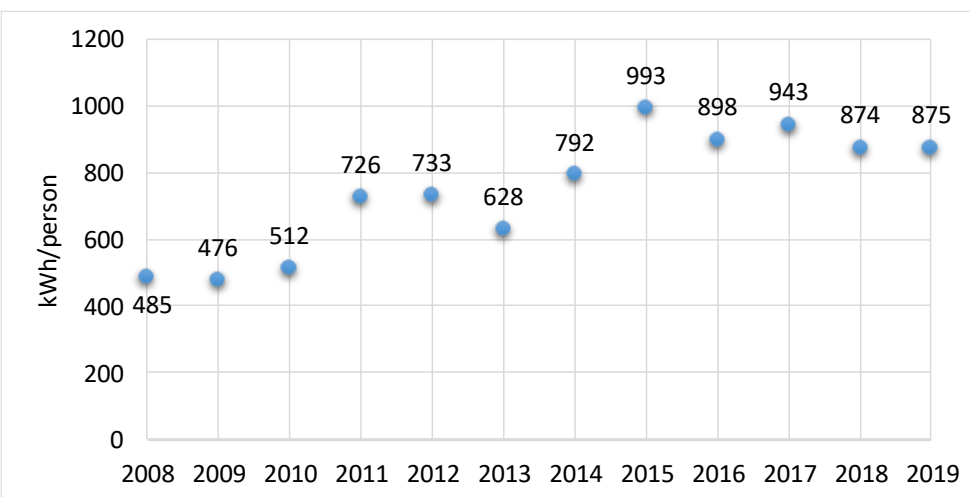

Figure 7. Annual total natural gas consumption per person

Total annual electricity consumption values are shown in Figure 8 . It is observed that the annual total electricity consumption has increased steadily with an average growth rate of $23.62 \%$. The main reason for this can be the increase in the number of buildings, the greatly improved physical conditions of education and training, and the rise in the number of students. Electricity consumption is the sum of energy for cooling and lighting. Therefore, it could not be associated with changes in air temperatures.

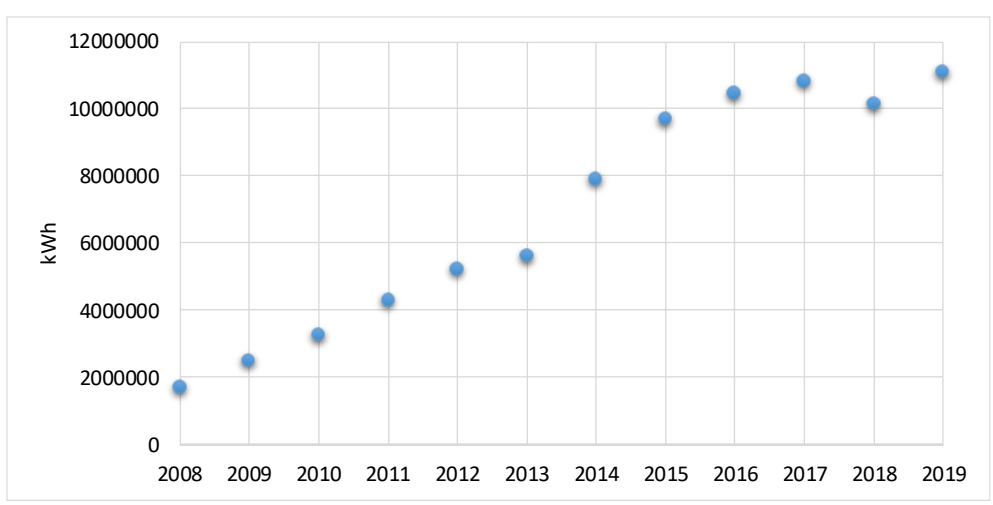

Figure 8. Annual total electricity consumption

Figure 9 shows the annual electricity consumption per person. In 2008, $143 \mathrm{kWh} /$ person electricity consumption was realized. It increased every year and reached to $482 \mathrm{kWh} /$ person in 2019.

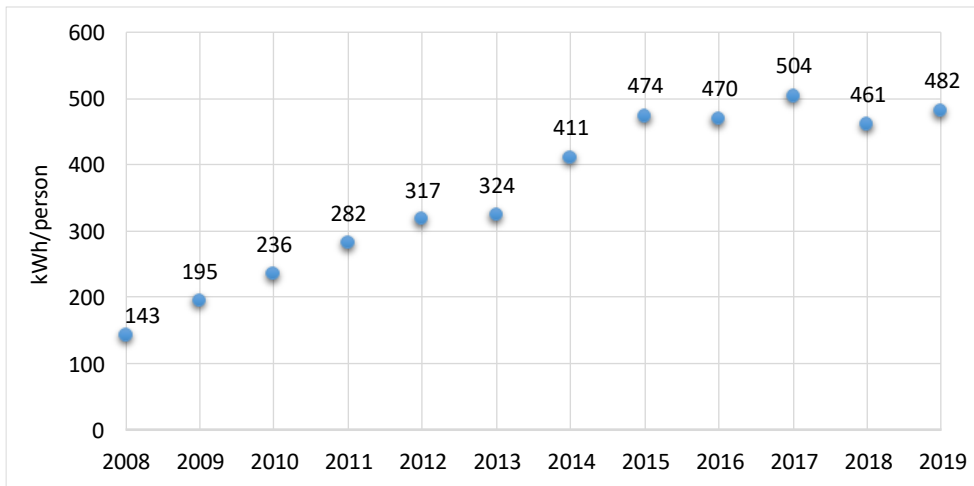

Figure 9. Annual total electricity consumption per person

\subsection{Natural Gas and Electricity Consumption by Buildings}

Normalization of energy consumption data makes it easier to compare buildings with the others. One of the normalization approaches is the calculation of energy use intensities. In Figure 10, energy use intensity indicator for the total natural gas and electricity consumption are given for all buildings between 20082019. It is very clear that there are important differences between the buildings. The amount of natural gas 
consumed per unit area in the Faculty of Medicine Hospital, which started operating in 2014, has the highest value with $1930 \mathrm{kWh} / \mathrm{m}^{2}$. The most important reason for this is that hospitals are used for 24 hours compared to other buildings. Medico Social building is in the second place with $1728 \mathrm{kWh} / \mathrm{m}^{2}$ natural gas consumption. The reason for this is that the Faculty of Medicine Hospital, which was established in August 2009, started to serve in this building and continued to until 2014. The Dining Hall is in the third place with $1348 \mathrm{kWh} / \mathrm{m}^{2}$. All meals for staff and students are cooked in that place. Therefore, consumption in this building includes both heating and cooking processes. They are followed by the Rectorate of building, Faculty of Science and Letters and Faculty of Engineering and Architecture. Natural gas consumption per unit area has the lowest values in the Faculty of Engineering and Faculty of Medicine. The reason for this is that these buildings were started to use in 2017. It is sense that the consumption values of old buildings are higher than new buildings.
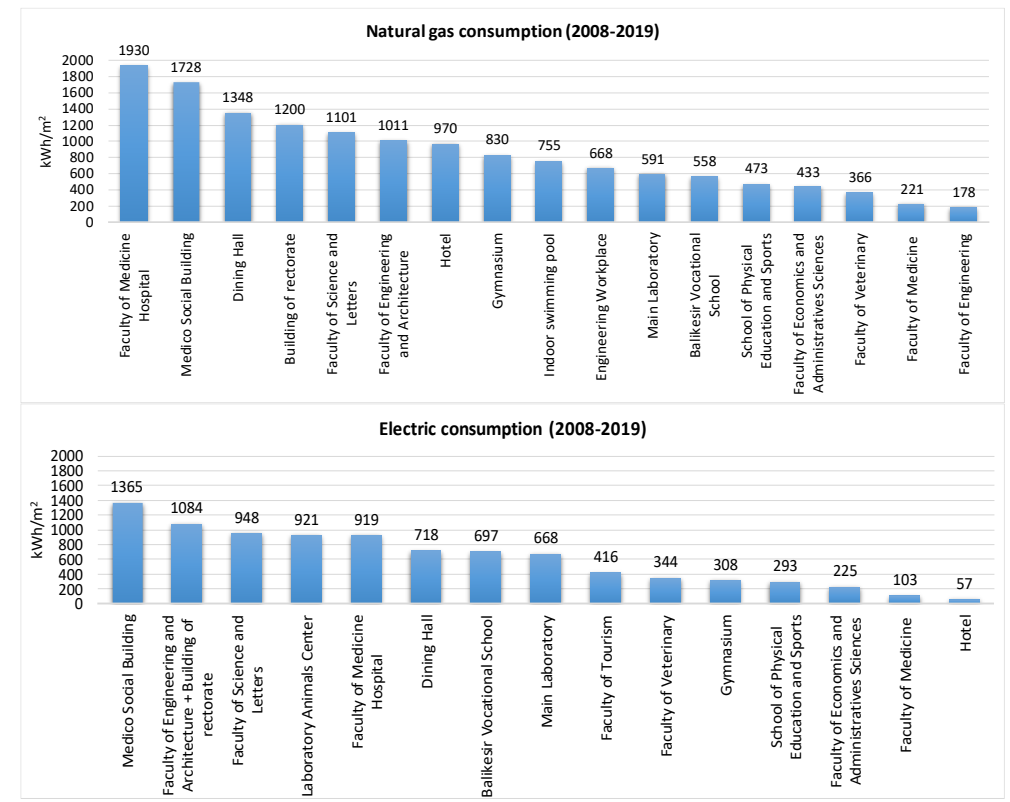

Figure 10. Natural gas and electricity consumption for buildings

As can be seen in Figure 10, there are big differentiation in electricity consumption per unit area among buildings. Medico Social building has the highest value with $1365.1 \mathrm{kWh} / \mathrm{m}^{2}$ electricity consumption. The most important cause for this is that the building has been used for various purposes since 2009 and it served as a Faculty of Medicine hospital. The Faculty of Engineering and the Rector's Office is in second place. The Faculty of Science and Letters is one of the buildings used since 2008 and it is the third building with the highest energy consumption. Another point that draws attention here is that the consumption value of Laboratory Animals Center, which started to use in 2015, is higher than many buildings. The probable reason for this is that the indoor temperature is kept around $22^{\circ} \mathrm{C}$ for 24 hours due to the animals living in this building. Although the Faculty of Medicine Hospital was opened in 2014, a significant consumption was realized with $919.5 \mathrm{kWh} / \mathrm{m}^{2}$. The Faculty of Medicine and hotel building have the lowest consumption values. The reason for this may be the absence of cooling system in hotel building and the Faculty of Medicine is a new building constructed in 2017.

Due to the fact that not every building is used at the same time, there are differences in total energy consumption. To eliminate this impact, energy use intensities were calculated and compared based on consumption values in 2019. The annual natural gas and electricity consumption of the buildings per unit area are given in Figure 11. The Faculty of Medicine Hospital has the highest total energy consumption per unit area with $506 \mathrm{kWh} / \mathrm{m}^{2}$. The reason for this is that it serves as a hospital and is used 24 hours a day. Then Laboratory Animals Center comes with $319 \mathrm{kWh} / \mathrm{m}^{2}$. The reason for the high consumption is that the indoor temperature is kept at $22^{\circ} \mathrm{C}$ for 24 hours. The third rank is the Faculty of Engineering and Architecture and the Building of Rectorate. It is in the front row due to the consumption amount belongs to the two buildings. It is seen that the consumption in the Main laboratory building is higher than the consumption in other buildings. This is thought to be caused by the electrical devices used in the center. 
The fact that electricity consumption for this building is higher than natural gas consumption strengthens this possibility. It is noteworthy that the consumption in the main laboratory building is higher than the consumption values in almost all educational buildings. Taking special measures will be beneficial in terms of energy efficiency for these kinds of buildings. With the use of $197 \mathrm{kWh} / \mathrm{m}^{2}$ in the Dining Hall, more energy was consumed than the use in educational buildings. In this building, food service is provided to students and staff twice a day. Meals are also cooked in the same building. Electric energy consumption is similarly high. The education building with the highest total energy consumption is the Faculty of Arts and Sciences with $178 \mathrm{kWh} / \mathrm{m}^{2}$. Then the Faculty of Veterinary comes with $142 \mathrm{kWh} / \mathrm{m}^{2}$. The use of this building as both an education and an hospital are thought to increase consumption. Faculty of Economics and Administrative Sciences has low energy consumption with $106 \mathrm{kWh} / \mathrm{m}^{2}$ total energy usage. It can be said that this building uses energy more efficiently than other buildings. The Faculty of Engineering building is among the energy efficient buildings in terms of energy consumption for heating purposes. In terms of electricity consumption, it can be said that the Faculty of Medicine is energy efficient. These buildings are also newly built buildings.

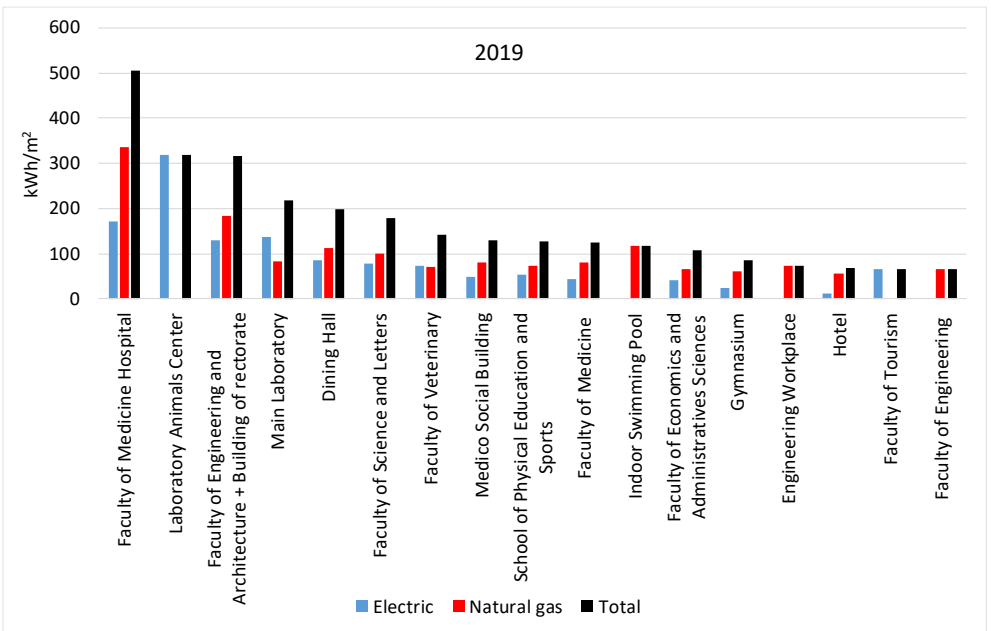

Figure 11. Natural gas and electricity consumption per unit area in 2019

\subsection{Contribution of Campus Buildings to Total Energy Consumption}

In order to help the energy auditing in the campus buildings, it is necessary to determine the buildings contributing highly to the total energy consumption of the campus in more detail. The contribution of the examined buildings to the total energy consumption of campus is calculated by the following formula:

S: Contribution to total consumption

$$
\mathrm{S}=\frac{B_{\text {Total }}}{\sum_{i=1}^{n} B_{\text {Total }}} \times 100 .
$$

$\mathrm{B}_{\text {total: }}$ Total electricity and natural gas consumption of a building

$\mathrm{n}$ : Number of buildings inspected

Figure 12 shows the contribution of the examined buildings to the total energy consumption between 20082019. The building which has the biggest share in the total energy consumption in Balikesir University Çağ 1 Ş Campus is the Faculty of Medicine hospital with $31 \%$. The Faculty of Engineering and Architecture and the Building of Rectorate are responsible for $18.8 \%$ of the total energy consumption. It is very clear that the first five buildings are responsible from $70 \%$ of the total energy consumption of Çağış Campus. The other 13 buildings are responsible for only $30 \%$ of total energy consumption. Energy efficient improvements of the first five buildings has great potential to reduce energy demand of the entire campus. The contribution of the indoor swimming pool, the Faculty of Engineering and the Engineering workplace to the total energy consumption is less than $1 \%$. It would not be logical to produce energy saving strategies for these buildings. 


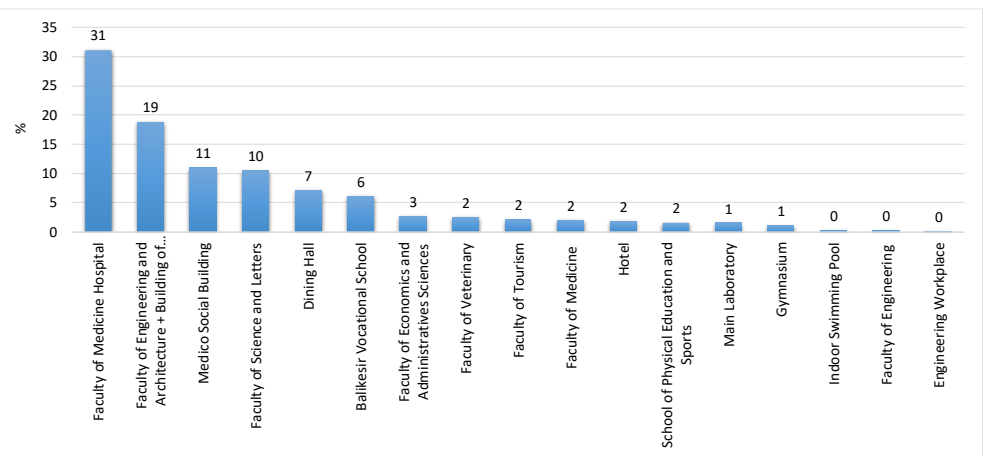

Figure 12. The contribution of individual buildings to total energy consumption in campus (2008-2019)

\subsection{The Comparison of with International Energy Consumptions}

The studies showing energy consumption data of educational buildings is available in literature. This section provides a comparative analysis of the energy consumption of 32 different educational buildings from the world and Balikesir University Çağış Campus. According to Figure 13, it varied from about 58 to $739 \mathrm{kWh} / \mathrm{m}^{2}$ year. In other words, the energy consumptions in educational buildings change significantly. It was seen that while energy consumption at the Faculty of Engineering + the Building of rectorate was higher than many university buildings, it is lower than energy use in Yale, Kyota and Keio university buildings which are highest energy intensive campus buildings in comparison with other countries. The amount of energy consumed in the Faculty of Science and Letters was higher than the 17 education buildings worldwide, while it is lower than the 15 education buildings. Faculty of Economics and Administrative Sciences ranks 23rd out of 32 educational buildings. Faculty of Tourism and Faculty of Engineering are almost at the last places. This means that less energy in these buildings was consumed than many educational buildings. In addition to these, the ASHRAE Standard 90.1 determined baseline values in university buildings as $403 \mathrm{kWh} / \mathrm{m}^{2}$ for electricity and $733 \mathrm{kWh} / \mathrm{m}^{2}$ for gas [30]. It is clear that energy consumptions of university buildings in Çağış campus in 2019 was lower than proposed values given in ASHRAE Standard 90.1.

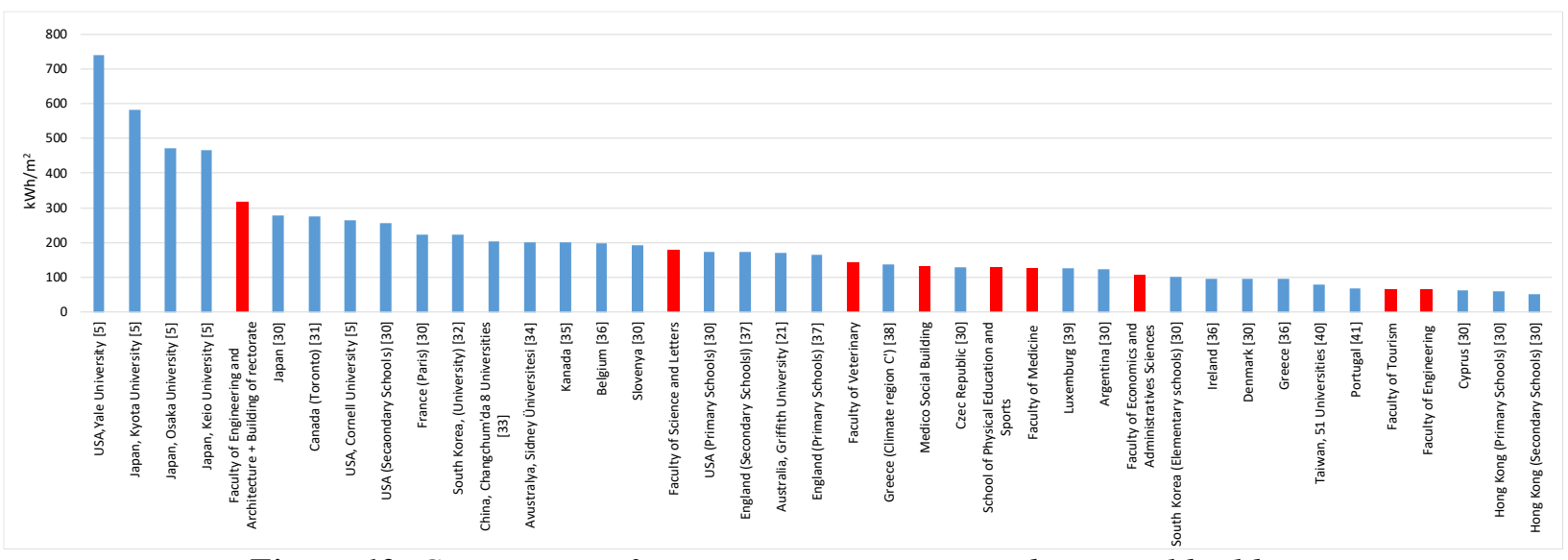

Figure 13. Comparison of energy consumptions in educational buildings

\section{CONCLUSION}

This study is the first to provide empirical evidence on the energy consumption of buildings in Balıkesir University. It is helpful to evaluate, analyse, diagnose the energy consumption of the buildings and useful to understand energy characteristics of different educational buildings. For this reason, this study aimed to examine and compare actual energy consumption of university buildings and provide basic data for the energy management of university campuses. The focus of this paper is on total energy consumption, including both heating and electricity. This study shows that the variety of energy use of the studied buildings is high regardless of age and type of building. This means that there is a need to find effective 
ways to reduce energy demands. The limit in this study is that buildings from only one university were studied. This may cause some inefficient buildings to be considered efficient. The results can guide authorities to promote energy saving and anticipating future planning for energy management. In brief the main conclusions are the followings:

- The energy consumption of all individual buildings for the years 2008-2019 has been in the range of $178-1930 \mathrm{kWh} / \mathrm{m}^{2}$ for heating and $57-1365 \mathrm{kWh} / \mathrm{m}^{2}$ for electricity.

- The energy use of all buildings in 2019 changed between $56-334 \mathrm{kWh} / \mathrm{m}^{2}$ for heating and $12-319$ $\mathrm{kWh} / \mathrm{m}^{2}$ for electricity.

- The Faculty of Medicine hospital, Faculty of Engineering and Architecture, Building of Rectorate, Medico social building and Faculty of Arts and Sciences are responsible 70\% of the total energy consumed in Çağ 1 ç campus between 2008-2019. It is possible to reduce an important amount of energy demand in Çağış campus by retrofitting only five buildings.

- Compared to other buildings, Faculty of Economics and Administrative Sciences has relatively lower energy consumption. It can be said that this building is energy efficient compared to other buildings. The Faculty of Engineering building is among the energy efficient buildings in terms of heating energy consumption. In terms of electricity consumption, it can be said that the Faculty of Medicine building uses energy efficiently.

- The amount of energy consumption in educational buildings in other countries varies considerably. Faculty of Tourism and Faculty of Engineering are the most energy efficient buildings compared to others.

Conducting similar studies for other universities can increase the amount of data. In this way, more information can be obtained by creating comparative analyses.

\section{ACKNOWLEDGEMENTS}

The present study is supported by Balikesir University with BAP project 2017/054.

\section{CONFLICTS OF INTEREST}

No conflict of interest was declared by the authors.

\section{REFERENCES}

[1] Pe'rez-Lombard, L., Ortiz, J., Pout, C., "A review on buildings energy consumption information", Energy and Buildings, 40: 394-398, (2008).

[2] Ouf, M. M., Issa, M.H., "Energy consumption analysis of school buildings in Manitoba, Canada", International Journal of Sustainable Built Environment, 6: 359-371, (2017).

[3] Janssen, R., “Towards Energy Efficient Buildings in Europe”, EuroACE Report, London, 45-50, (2005).

[4] IPCC., "Climate Change 2007: Impacts, Adaptation and Vulnerability", New York, 100-103, (2007).

[5] Ma, Y., Lu, M., Weng, J., "Energy consumption status and characteristics analysis of university campus buildings", Proceedings of the 5th International Conference on Civil Engineering and Transportation, Korea, 1240-1243, (2015).

[6] Alshuwaikhat, H. M., Abubakar, I., "An integrated approach to achieving campus sustainability: assessment of the current campus environmental management practices", Journal of Cleaner Production, 16(16): 1777-1785, (2008). 
[7] Heidarinejad, M., Cedeno-Laurent, J.C., Wentz, J.R., Rekstad, N.M., Spengler, J.D., Srebric, J., "Actual building energy use patterns and their implications for predictive modeling", Energy Conversion and Management, 144: 164-180, (2017).

[8] Yükseköğretim Kurulu, "Yükseköğretim Kurulu 2016-2020 Stratejik Planı", Ankara, 78-82, (2015).

[9] Çetinsaya, G., "Büyüme, Kalite, Uluslararasılaşma: Türkiye Yükseköğretimi İçin Bir Yol Haritası", Yayın No: 2014/2, Eskişehir: Anadolu Üniversitesi Basımevi. 45-50, (2014).

[10] https://istatistik.yok.gov.tr/ Access date: 09.03.2020.

[11] Koçyiğit, F. B., "Zero Consumption Monotype Education Buildings", Gazi University Journal of Science, 31(2): 328-340, (2018).

[12] Hong, W. H., Kim, J. Y., Lee, C. M., Jeon, G.Y., "Energy consumption and the power saving potential of a University in Korea: using a field survey", Journal of Asian Architecture and Building Engineering, 10(2): 445-452, (2011).

[13] Hawkins, D., Hong, S.M., Raslan, R., Mumovic, D., Hanna, S., "Determinants of energy use in UK higher education buildings using statistical and artificial neural network methods", International Journal of Sustainable Built Environment, 1(1): 50-63, (2012).

[14] Deshko, V. I., Shevchenko, O. M., "University campuses energy performance estimation in Ukraine based on measurable approach", Energy and Buildings, 66: 582-590, (2013).

[15] Zhou, X., Yan, J., Zhu, J., Cai, P., "Survey of energy consumption and energy conservation measures for colleges and universities in Guangdong province", Energy and Buildings, 66: 112118, (2013).

[16] Escobedo, A., Briceno, S., Juárez, H., Castillo, D., Imaz, M., Sheinbaum, C., "Energy consumption and GHG emission scenarios of a university campus in Mexico", Energy for Sustainable Development, 18: 49-57, (2014).

[17] Chung, M.H., Rhee, E.K., "Potential opportunities for energy conservation in existing buildings on university campus: a field survey in Korea”, Energy and Buildings, 78: 176-182, (2014).

[18] Guan, J., Nord, N., Chen, S., "Energy planning of university campus building complex: Energy usage and coincidental analysis of individual buildings with a case study", Energy and Buildings, 124: 99-111, (2016).

[19] Sait, H. H., "Auditing and analysis of energy consumption of an educational building in hot and humid area", Energy Conversion and Management 66: 143-152, (2013).

[20] Sekki, T., Airaksinen, M., Saari, A., "Measured energy consumption of educational buildings in a Finnish city", Energy and Buildings, 87: 105-115, (2015).

[21] Khoshbakht, M., Gou, Z., Dupre, K., "Energy use characteristics and benchmarking for higher education buildings", Energy and Buildings, 164: 61-76, (2018).

[22] Lukman, R., Tiwary, A., Azapagic, A., "Towards greening a university campus: The case of the University of Maribor, Slovenia. Resources", Conservation and Recycling, 53(11): 639-644, (2009). 
[23] Brown, K., Anderson, M., Harris, J., "Setting enhanced performance targets for a new university campus: benchmarks vs. energy standards as a reference?", Proceedings of the 2002 ACEEE Summer Study of Energy Efficiency in Buildings, Washington, 29-40, (2002).

[24] Evangelios, K.I., Jones, N., Panoriou, E. M., "Challenges and opportunities for sustainability in regional universities: a case study in Mytilene Greece", Journal of Cleaner Production, 17(12): 1154-1161, (2009).

[25] Bertone, E., Sahin, O., Stewart, R.A., Zou, P., Alam, M., Blair, E., "State-of-the-art review revealing a roadmap for public building water and energy efficiency retrofit projects", International Journal of Sustainable Built Environment, 5: 526-548, (2016).

[26] Chung, W., "Review of building energy-use performance benchmarking methodologies", Applied Energy, 88: 1470-1479, (2011).

[27] http://www.balikesir.edu.tr/ Access date: 21.03.2020.

[28] https://www.mgm.gov.tr/FILES/iklim/yillikiklim/2011-iklim-raporu.pdf Access date: 29.03.2020.

[29] https://www.mgm.gov.tr/FILES/iklim/2013-yili-iklim-degerlendirmesi.pdf Access date: 19.03.2020.

[30] ANSI/ASHRAE/IES Standard 90.1-2019, Energy Standard for Buildings Except Low-Rise Residential Buildings, American Society of Heating, Refrigerating and Air-Conditioning Engineers Inc., Atlanta (2019). 